\title{
Zbieg sankcji podatkowych i karnych w świetle Konwencji o Ochronie Praw \\ Człowieka i Podstawowych Wolności
}

\section{Concurrence of tax and criminal sanctions in the light of the Convention for the Protection of Human Rights and Fundamental Freedoms}

Streszczenie. Kumulacja odpowiedzialności z tytułu sankcji podatkowych oraz karnych skutkuje koniecznością wyeliminowania możliwości stosowania jednocześnie sankcji podatkowych oraz karnych z uwagi na uniwersalną zasadę niedopuszczalności wielokrotnego karania tej samej osoby za ten sam czyn. Jednocześnie granice, w jakich zarówno ustawodawca, jak i organ stosujący prawo może się poruszać, wynikające z art. 4 Protokołu nr 7 do Konwencji o Ochronie Praw Człowieka i Podstawowych Wolności precyzuje orzecznictwo Europejskiego Trybunału Praw Człowieka. W artykule autor przeanalizował orzecznictwo Trybunału, poszukując kryteriów, które są wykorzystywane do zakwalifikowania sankcji podatkowych jako spełniających wymogi Konwencji. 
Słowa kluczowe: sankcje; sankcje podatkowe; kary kryminalne; ochrona praw podatnika; zakaz podwójnego karania.

\begin{abstract}
This paper analyses an applicability of a rule not to be punished twice in case of the concurrence of tax and criminal sanctions. The Author studied limits of legislator's power to set the regulations connected with concurrence of tax and criminal sanctions and limits established by international law. In the Author's opinion the main barriers in establishing such limits arise from the Convention for the Protection of Human Rights and Fundamental Freedoms and judgments of the European Court of Human Rights.
\end{abstract}

Keywords: sanctions; tax sanctions; criminal penalties; protection of taxpayer's rights; right not to be punished twice.

\title{
1. Wstęp
}

Problematyka zbiegu sankcji podatkowych z sankcjami karnymi stanowiła kilkukrotnie przedmiot orzeczeń Trybunału Konstytucyjnego oraz sądów administracyjnych ${ }^{1}$. Jakkolwiek orzecznictwo Trybunału Konstytucyjnego ustaliło kryteria oceny zgodności w tym zakresie przepisów z Konstytucją RP, wywodząc zakaz kumulowania odpowiedzialności z art. 2 Konstytucji Rzeczypospolitej Polskiej z 2 kwietnia 1997 r. ${ }^{2}$, to równie istotne są w tym zakresie granice, jakie zakreślają regulacje prawa międzynarodowego. Szczególną rolę odgrywają postanowienia Protokołu Nr 7 do Konwencji o ochronie praw człowieka i podstawowych wolności sporządzo-

1 Zob. np. wyrok Trybunału Konstytucyjnego z 29 kwietnia 1998 r., K 17/97, „Orzecznictwo Trybunału Konstytucyjnego Zbiór Urzędowy” 1998, nr 3, poz. 30; wyrok Trybunału Konstytucyjnego z 30 listopada 2004 r., SK 31/06, „Orzecznictwo Trybunału Konstytucyjnego Zbiór Urzędowy” 2004, nr 10, poz. 110; wyrok Trybunału Konstytucyjnego z 4 września 2007 r., P 43/06, „Orzecznictwo Trybunału Konstytucyjnego Zbiór Urzędowy” 2007, nr 8, poz. 95; wyrok Trybunału Konstytucyjnego z 18 czerwca 2001 r., P 6/00, „Orzecznictwo Trybunału Konstytucyjnego” 2001, nr 5, poz. 120; uchwała Naczelnego Sądu Administracyjnego z 16 października 2006 r., I FPS 2/06, Centralna Baza Orzeczeń Sądów Administracyjnych (CBOSA); uchwała Naczelnego Sądu Administracyjnego z 14 marca 2005 r., FPS 1/04 (CBOSA). Zob. także wyrok Sądu Najwyższego z 21 maja 2002 r., III RN 64/01, „Monitor Podatkowy” 2003, nr 3, s. 33-34.

2 Dz.U. Nr 78, poz. 483 ze zm. 
nego 22 listopada 1984 r. w Strasburgu ${ }^{3}$ w zakresie, w jakim przewidują zakaz ponownego sądzenia lub karania. Podkreślić należy, że sama Konwencji o Ochronie Praw Człowieka i Podstawowych Wolności sporządzona w Rzymie w dniu 4 listopada 1950 r. ${ }^{4}$ w doktrynie uznawana jest za skuteczny instrument przeciwdziałania nadmiernej ingerencji państwa również w sferę wolności i praw podatnika ${ }^{5}$. Skuteczność regulacji Konwencji wynika przy tym głównie z roli, jaką odgrywa orzecznictwo Europejskiego Trybunał Praw Człowieka (dalej ETPC lub Trybunał). Na marginesie podkreślić należy, że równie istotną rolę w analizie problematyki zbiegu sankcji odgrywają postanowienia prawa unijnego oraz orzecznictwo Trybunału Sprawiedliwości Unii Europejskiej, jakkolwiek ich specyfika ograniczona jest do ochrony wartości traktatowych. Regulacje dotyczące zbiegu odpowiedzialności przewiduje również art. 14 pkt 7 Międzynarodowego Paktu Praw Obywatelskich i Politycznych z dnia 19 grudnia 1966 r. ${ }^{6}$, przy czym w doktrynie podkreśla się, że Pakt Praw w porównaniu z Europejską Konwencją ma w Europie niewielkie znaczenie z punktu widzenia ochrony prawa podatnika z uwagi na ograniczone kompetencje Komitetu Praw Człowiek ONZ ${ }^{7}$.

Przedmiotem niniejszego opracowania jest analiza regulacji prawnych dotyczących zbiegu sankcji podatkowych oraz karnych w zakresie z wykorzystaniem metody dogmatyczno-prawnej wspartej o analizę orzecznictwa. Celem analizy jest ustalenie granic, w jakich regulacje prawa międzynarodowego dotyczą zbiegu tych sankcji, oraz identyfikacja związanych z tym problemów normatywnych, zmierzająca do zaproponowania kierunków zmian legislacyjnych.

Dz.U. z 2003 r. Nr 42, poz. 364, dalej jako „Protokół nr 7”.

Dz.U. z 1993 r. Nr 61, poz. 284 ze zm., dalej jako „Konwencja”.

Zob. A. Leszczyńska, Europejska Konwencja o Ochronie Praw Człowieka oraz Podstawowych Wolności jako instrument ochrony praw podatnika, „Kwartalnik Prawa Podatkowego” 2004, nr 1-2, s. 9 i n.; A. Mudrecki, Ochrona praw podatników w świetle orzecznictwa Europejskiego Trybunału Praw Człowieka w Strasburgu, „Krytyka Prawa” 2020, nr 1, s. 1-17.

$6 \quad$ Dz.U. z 1977 r. Nr 38, poz. 167.

7 B. Szczurek, Koncepcja ochrony praw podatnika. Geneza, rozwój, perspektywy, Warszawa 2008, s. 119. 


\section{Pojęcie i charakter sankcji podatkowych oraz karnych}

Przepisy Konwencji nie posługują się pojęciem sankcji podatkowej lub terminem równorzędnym, podobnie nie pojawia się w ich treści pojęcie podatku. Jest to wynikiem tego, że Konwencja w założeniu chroni prawa człowieka oraz podstawowe wolności poprzez ustanawianie standardów, nie wyodrębniając przy tym zakresu ochrony dla poszczególnych gałęzi prawa. Każdorazowo należy zatem przeprowadzać analizę poszczególnych regulacji Konwencji co do tego, czy w ich zakresie mieści się ochrona praw związana ze stosowaniem danej instytucji.

Sankcję podatkową należy zdefiniować jako wynikającą z norm prawa podatkowego konsekwencję naruszenia obowiązków norm materialnych tego prawa przez jego adresata będącego podmiotem biernym, które z punktu widzenia jego interesu ekonomicznego wywołuje powstanie niekorzystnej sytuacji prawnej lub faktycznej w stosunku do sytuacji, jaka powstałaby, gdyby adresat nie naruszył normy, oraz w ocenie prawodawcy będą traktowane jako kara za naruszenie prawa ${ }^{8}$. Sankcje należy wiązać się z dolegliwością polegającą na pogorszeniu sytuacji faktycznej bądź prawnej, będącym reakcją na naganne zachowanie podatnika lub innego podmiotu, na którego prawo podatkowe nałożyło obowiązki - za niewykonanie bądź nieprawidłowe wykonanie tych obowiązków, które w założeniu powinno zniechęcić do nagannego działania potencjalnego sprawcę, a innym podmiotom pokazać konsekwencję organów władzy publicznej w egzekwowaniu prawa ${ }^{9}$.

Przedstawiona wyżej definicja sankcji podatkowej jest zbieżna z definicjami proponowanymi $\mathrm{w}$ doktrynie prawa podatkowego ${ }^{10}$. Jednocze-

8 Por. P. Majka, Sankcje w prawie podatkowym, Warszawa 2011, s. 60; w doktrynie podkreśla się jednocześnie, że wątpliwym jest, czy zamiar karania jest istotną cechą definicyjną sankcji podatkowej z uwagi na to, że jest to cecha empirycznej obserwacji funkcjonowania instytucji uważanych za sankcje podatkowe (B. Brzeziński, Prawo podatkowe. Zagadnienia teorii i praktyki, Toruń 2017, s. 458).

9 B. Brzeziński, Prawo podatkowe. Zagadnienia..., s. 458.

10 M. Duda, Pojęcie i charakter sankcji podatkowych, „Prawo-Administracja-Kościół” 2002, nr 2-3, s. 60 i n.; H. Dzwonkowski, Konstytucyjność sankcji podatkowych, „Monitor Podatkowy” 1999, nr 3, s. 22-23; A. Gomułowicz, J. Małecki, Podatki 
śnie rozwinięcia wymagają te elementy definicji sankcji, o które została ona uzupełniona w zestawieniu z definicjami przyjmowanymi w literaturze. Przede wszystkim nie wydaje się konieczne wskazanie w definicji sankcji podatkowej tego, że z sankcją związane jest stosowanie przymusu. Pojęcia przymusu prawnego i sankcji nie są bowiem tożsame ${ }^{11}$. W prawie podatkowym możliwa jest z kolei sytuacja, w której naruszenie normy skutkuje dolegliwością pozbawioną cechy przymusu. Sytuację taką ilustruje przykład odebrania podatnikowi uprawnień (np. prawa do korzystania z preferencyjnej formy opodatkowania), jeżeli nie dotrzymuje określonych przepisami prawa warunków poprzez niewykonywanie nałożonego obowiązku lub naruszanie innych norm prawa. Nie występuje tu element przymusu, lecz w związku z naruszeniem prawa poprzez nałożenie sankcji zmieniona zostaje na mniej korzystną sytuacja prawna podatnika.

Zgodnie z przyjętą definicją sankcji podatkowej z naruszeniem normy podatkowoprawnej musi wiązać się niewykonanie lub wadliwe wykonanie nałożonego obowiązku. Podkreślenie w przyjętej definicji elementu obowiązku jest skutkiem założenia, że nieskorzystanie przez podatnika z przyznanych mu uprawnień nie powinno być traktowane jako sankcja prawna. Bodziec prawny zachęcający do podejmowania określonej czynności poprzez obietnicę korzyści nie może być bowiem na płaszczyźnie normatywnej rozważany w kategoriach sankcji, która z założenia dotyczy naruszeń prawa i związanych z nimi dolegliwości. Odmiennie należy jednak klasyfikować konsekwencję wadliwego korzystania z już przyznanych podatnikowi uprawnień. W sytuacji, w której podatnik korzysta z przyznanego uprawnienia, naruszając określone prawem warunki (np. poprzez niewykonywanie w terminie innych zobowiązań podatkowych), konsekwencję pozbawienia tych uprawnień należy traktować jako sankcję podatkową za naruszenie obowiązku. Obowiązkiem określonym w dyspo-

i prawo podatkowe, Warszawa 2006, s. 202-203; M. Gontarczyk, Sankcje finansowe i karne skarbowe jako instrument ochrony publicznej gospodarki finansowej, Lublin 2006, s. 87-88; J. Małecki, Z problematyki sankcji w prawie podatkowym ze szczególnym uwzględnieniem podatku VAT [w:] B. Brzeziński, J. Głuchowski, C. Kosikowski, R. Mastalski (red.) Księga pamiq̨tkowa ku czci prof. A. Kosteckiego. Studia z dziedziny prawa podatkowego, Toruń 1998, s. 155-156.

11 Szerzej P. Majka, Sankcje w prawie podatkowym..., s. 24-26. 
zycji normy podatkowej jest bowiem nakaz dochowania warunków uprawnienia.

W doktrynie prawa podatkowego nierozstrzygnięty pozostaje problem zakresu instytucji prawnych, które należy kwalifikować jako sankcje. W teorii prawa sankcje podatkowe definiuje się bowiem, opierając na przyjętym wyżej językowym znaczeniu wyrażenia „sankcja”, lub akcentuje potrzebę badania miejsca sankcji w strukturze normy prawnej. Odnosząc się do podejścia drugiego, należy podkreślić, że poszczególne teorie budowy normy prawnej inaczej umiejscawiają sankcję w jej strukturze ${ }^{12}$. Niezależnie jednak od przyjętej koncepcji, sankcja pełni zawsze rolę elementu obejmującego konsekwencje, które nastąpią w sytuacji, gdy adresat zachowa się niezgodnie $\mathrm{z}$ wzorem przyjętym w treści normy ${ }^{13}$. Przedstawione wyżej dwa ujęcia dają odmienne rezultaty odnośnie do zakresu instytucji prawnych kwalifikowanych jako sankcje. Językowe znaczenie terminu „sankcja” (przypisujące jej cechę dolegliwości) obejmuje bowiem mniejszą liczbę instytucji prawnych od sankcji rozumianej jako element budowy normy prawnej (tzn. obejmującej wszystkie konsekwencje naruszenia normy określanej również jako sankcje norm prawa podatkowego, w tym sankcje egzekucyjne). Obydwa ujęcia mają jednocześnie wspólny element, związany z główną funkcją sankcji podatkowej, którą jest zagwarantowanie skuteczności norm prawnych poprzez zagrożenie dolegliwością lub przymusowym wyegzekwowaniem nakazanego zachowania ${ }^{14}$.

Jednocześnie zaproponować można metodę umożliwiającą rozróżnienie sankcji podatkowych na tle pozostałych skutków naruszenia norm wynikających z prawa podatkowego ${ }^{15}$. Odwołując się do charakteru prawa podatkowego, należy w pierwszej kolejności stwierdzić, że sankcje podatkowe, które ze swej istoty stanowią dolegliwość, pomimo iż mogą wpłynąć na zwiększenie skuteczności jego norm, nie mogą stanowić podstawowej instytucji gwarantującej skuteczność norm prawa podatkowego ${ }^{16}$.

12 Szerzej na temat koncepcji budowy norm podatkowych zob. B. Brzeziński, Prawo podatkowe. Zagadnienia..., s. 411-414.

13 P. Majka, Sankcje w prawie podatkowym..., s. 96.

14 Tamże, s. 97.

15 Tamże, s. 65-66.

16 Por. B. Brzeziński, Prawo podatkowe. Zagadnienia..., s. 471. 
Oparcie wykonalności norm wyłącznie na sankcji o charakterze karnym spowodowałoby bowiem faktycznie zmianę charakteru tej gałęzi prawa. Można zatem dopuścić sytuację, w której ustawodawca rezygnuje ze stosowania jakichkolwiek sankcji podatkowych. Zabieg taki mógłby wpłynąć na skuteczność norm prawa podatkowego, jednak nie doprowadziłby do likwidacji instytucji tej gałęzi prawa z uwagi na to, że wykonanie norm gwarantuje nadal przede wszystkim egzekucja zobowiązań. Przeciwna zasada dotyczy z kolei sankcji typowo egzekucyjnych, ponieważ funkcjonowanie norm prawa podatkowego nie byłoby możliwe bez zagwarantowania przymusowego wyegzekwowania obowiązków wynikających z przepisów. Badając charakter danej instytucji zawierającej element dolegliwości jako ewentualnej sankcji podatkowej, można zatem dokonać weryfikacji negatywnej związanej z założeniem usunięcia jej z systemu prawa. Jeżeli brak tej instytucji w systemie prawa podatkowego spowoduje faktyczną niemożność jego prawidłowego funkcjonowania i powstanie w tym miejscu konstrukcyjna luka prawna, to należy przyjąć, że instytucja ta nie jest sankcją podatkową, lecz ma charakter „egzekucyjny” (np. szacowanie podstawy opodatkowania). Jeżeli natomiast usunięcie badanej instytucji nie spowoduje braku możliwości funkcjonowania regulacji podatkowych, jakkolwiek może wpłynąć na obniżenie ich skuteczności, to może ona, w sytuacji stwierdzenia pozostałych cech, mieć charakter sankcji podatkowej.

Różnorodność sankcji podatkowych powoduje, że w ramach ich systematyki istnieje możliwość stosowania różnych kryteriów podziałów. Zgodnie z najistotniejszym z praktycznego punktu widzenia kryterium skutków dla naruszającego normę, uszczegóławiając powstające niekorzystne sytuacje, sankcje podatkowe dzielą się na te, w wyniku których nałożone zostają dodatkowe obowiązki (z reguły są to dodatkowe zobowiązania podatkowe), te, w których zwiększona jest wysokość zobowiązania podatkowego (z uwagi na zwiększenie podstawy opodatkowania bądź stawki podatkowej), oraz te, w wyniku których naruszający normę traci korzyści wynikające z przyznanych praw (z reguły prawo do preferencyjnego opodatkowania). 
Ustalając istotę sankcji w prawie karnym, należy zaznaczyć, że prawo to stanowi dziedzinę, której normy przewidują sankcje w sposób głęboki ingerujące w sferę praw i wolności jednostki. W związku z koniecznością zapewnienia skuteczności prawa karnego prawodawca przewiduje bowiem różnego rodzaju środki stanowiące prawną reakcję na naruszenie norm. Środki te określane są łącznie jako sankcje związane z popełnieniem czynu zabronionego (środki karnoprawne), przy czym najistotniejsze znaczenie ma kara kryminalna. Pojęcie sankcji wynikających z prawa karnego jest przy tym znaczeniowo szersze od kary kryminalnej, ponieważ obejmuje nie tylko typowe kary orzekane w związku z popełnieniem przestępstwa, lecz również inne dolegliwości (np. środki karne oraz środki zabezpieczające), które z uwagi na specyfikę nie będą jednak przedmiotem dalszych analiz. Kara kryminalna to z kolei osobista dolegliwość wymierzana sprawcy przestępstwa stanowiąca reakcję ze strony państwa na popełniony czyn oraz wyrażająca jego społeczne potępienie ${ }^{17}$. Istotą tak rozumianej kary jest przede wszystkim ujemna reakcja na przestępstwo, objawiająca się w dolegliwości, bez której reakcja traci status kary kryminalnej $^{18}$. Istotą dolegliwości jest pozbawienie przestępcy cennych dla niego dóbr o charakterze osobistym bądź materialnym lub pozbawienie określonych praw. Dolegliwość związana z karą, jaką operuje prawo karne, usprawiedliwiona jest przekonaniem, że z punktu widzenia chronionych dóbr bez jej zastosowania powstaje większe zło wynikające z popełnionych czynów zabronionych ${ }^{19}$.

W teorii do najważniejszych cech kary kryminalnej, wyróżniających ją wśród szeroko rozumianych form społecznego sprzeciwu dla zachowań uznanych za niedopuszczalne, zalicza się nakładanie kary w imieniu państwa przez powołane do tego organy, największą dolegliwość wśród sankcji za naruszenie dóbr prawnych, konieczność przypisania sprawcy winy

\footnotetext{
A. Marek, Prawo karne, Warszawa 2005, s. 229.

M. Cieślak, $O$ węzłowych pojęciach zwiqzzanych z sensem kary, „Państwo i Prawo” 1969, nr 2, s. 200-201.

19 A. Zoll, Założenia polityki karnej w projekcie kodeksu karnego, „Państwo i Prawo” 1994, nr 5, s. 5.
} 
oraz jej ściśle osobistą dolegliwość ${ }^{20}$. Ważne jest również wskazanie na motywację, która leży u podstaw ujemnej reakcji społecznej na zachowanie zabronione, określane jako racjonalizacja kary. W odniesieniu do sankcji karnych istotną rolę odgrywają w szczególności racjonalizacje sprawiedliwościowa oraz celowościowa ${ }^{21}$. Racjonalizacja sprawiedliwościowa wiąże się z zasadą proporcjonalności i stanowi o sprawiedliwej odpłacie sprawcy za popełnione przez niego przestępstwo. Natomiast racjonalizacja celowościowa wiąże się z karaniem sprawcy przestępstwa po to, by osiągnąć jakiś cel (przede wszystkim zresocjalizować sprawcę) ${ }^{22}$.

Charakteryzując sankcję w prawie karnym, należy wskazać na specyficzny zespół regulacji prawa karnego chroniących stosunki o charakterze finansowoprawnym określany jako prawo karne skarbowe. W teorii uznaje się, że z uwagi na duży stopień samodzielności w zakresie własnych zasad odpowiedzialności prawo karne skarbowe stanowi odrębną dyscyplinę prawa, będącą wyspecjalizowanym działem prawa karnego ${ }^{23}$. Podstawowe regulacje prawa karnego skarbowego zawarte są $\mathrm{w}$ ustawie z dnia 10 września 1999 r. Kodeks karny skarbowy ${ }^{24}$ oraz w ustawie z dnia 28 października 2002 r. o odpowiedzialności podmiotów zbiorowych za czyny zabronione pod groźbą kary ${ }^{25}$.

Prawo karne skarbowe obejmuje także regulacje prawne dotyczące zasad odpowiedzialności, stosowania kar, prowadzenia postępowania oraz wykonywania rozstrzygnięć w związku z popełnieniem przestępstw lub wykroczeń o charakterze podatkowym, określane jako prawo karne podatkowe ${ }^{26}$. Odpowiedzialność za przestępstwo i wykroczenia skarbowe nie ma jednocześnie charakteru samodzielnej, lecz jest faktycznie ściśle powiązana $\mathrm{z}$ odpowiedzialnością za naruszenie norm podatkowych ${ }^{27}$.

20 J. Majewski [w:] A. Zoll (red.), Kodeks karny. Część ogólna. Komentarz, Tom I, Kraków 2004, s. 575-576.

A. Marek, Prawo karne...., s. 232.

K. Buchała, A. Zoll, Polskie prawo karne, Warszawa 1997, s. 406.

L. Wilk, Zagadnienia materialnego prawa karnego skarbowego, Toruń 2004, s. 15-18.

Tekst jedn. Dz.U. z 2020 r., poz. 19 ze zm.

Tekst jedn. Dz.U. z 2020 r., poz. 358.

B. Brzeziński, Prawo podatkowe. Zagadnienia..., s. 391.

7 W. Wójtowicz, Przestępstwa i wykroczenia podatkowe, „Monitor Podatkowy” 1995, nr 1 , s. 4. 
W szczególności związek pomiędzy prawem karnym podatkowym a prawem podatkowym wynika z treści znamion przedmiotowych poszczególnych czynów zabronionych, tworzące wzory zabronionych zachowań. Treść znamion przestępstw i wykroczeń podatkowych jest bowiem zawsze w większym bądź mniejszym stopniu związana z naruszeniem obowiązków wynikających z prawa podatkowego ${ }^{28}$.

Powyżej wskazane związki różnych rodzajowo sankcji uzasadniają istnienie wspólnych płaszczyzn badawczych, na których należy prowadzić jednoczesne analizy sankcji podatkowych oraz prawa karnego. Stwierdzić bowiem należy, że jakkolwiek sankcje te przynależą do dwóch różnych dziedzin prawa, to łączy je główny cel wprowadzenia (zagwarantowanie skuteczności norm prawnych) oraz podobny charakter prawny, co w sytuacji, gdy chronią to samo dobro, powoduje ich związek funkcjonalny. W tym kontekście pojawia się problem kryteriów rozgraniczających ustanawianie poszczególnych sankcji. Tworząc system sankcyjnego oddziaływania na zobowiązanych, ustawodawca może bowiem przypisać konkretnym zachowaniom różne rodzaje sankcji, w tym także kary kryminalne. Problemem wymagającym każdorazowo rozstrzygnięcia w procesie tworzenia prawa jest więc to, które kategorie zachowań zostaną poddane sankcjom karnym, a które sankcjom właściwym wyłącznie dla prawa podatkowego $^{29}$, ewentualnie czy ustawodawca powinien poprzestać na zagwarantowaniu wykonania norm tylko w drodze przymusowej egzekucji administracyjnej oraz wymierzeniu odsetek za zwłokę. Dodatkowo w wypadku naruszenia obowiązków o charakterze instrumentalnym wobec zapłaty podatku możliwe jest również wykorzystanie administracyjnych kar pieniężnych ${ }^{30}$.

Wskazanie na właściwe kryteria rozgraniczające stosowanie sankcji podatkowych oraz pozostałych jest jednocześnie zadaniem złożonym, które wymaga prowadzenia szerokich, wieloaspektowych badań. Problem wyboru kryteriów rozgraniczających różne typy sankcji nie stanowi przy

28 B. Brzeziński, Prawo podatkowe. Zagadnienia..., s. 392.

29 Tamże, s. 469.

30 Zob. Dział IVA „Administracyjne kary pieniężne” ustawy z dnia 14 czerwca 1960 r. Kodeks postępowania administracyjnego (tekst jedn. Dz.U. z 2021 r., poz. 735). 
tym zagadnienia, które można rozstrzygnąć wyłącznie w ramach analizy norm jednej gałęzi prawa, z uwagi na to, że pozostaje on ściśle związany z szeroką problematyką polityki tworzenia prawa.

Podkreślić należy, że aktualnie zarówno w teorii, jak i w praktyce nie wypracowano jednoznacznych kryteriów wskazujących, jaką rodzajowo sankcję należy zastosować, by wprowadzona regulacja podatkowa była skuteczna oraz jednocześnie zgodna z prawem ${ }^{31}$. Abstrahując od propozycji konkretnych kryteriów, należy stwierdzić, że decyzja o wyborze określonej sankcji, która zapada w toku prac legislacyjnych, powinna być przy tym oparta na założeniu, że przyjęte rozwiązanie wpłynie na zwiększenie skuteczności norm podatkowych, nie naruszając jednocześnie obowiązujących granic, wynikających również z norm prawa międzynarodowego.

\section{Zbieg sankcji i ich kwalifikacja jako podlegających regulacjom Konwencji}

Z problemem rozgraniczenia zakresu stosowania różnych rodzajów sankcji wiąże się zagadnienie skutków naruszenia jednym zachowaniem kilku różnych norm. Jedno zachowanie, polegające na naruszeniu normy, może bowiem wyczerpywać hipotezy kilku norm wynikających z różnych gałęzi praw. W efekcie zbiegu różnych rodzajowo sankcji na etapie stosowania prawa pojawi się problem, czy należy stosować negatywne konsekwencje wszystkich zbiegających się norm, czy też ograniczyć się do zastosowania wybranej sankcji oraz którą z sankcji zastosować. W dalej prowadzonej analizie problem zbiegu sankcji zostanie przy tym odniesiony wyłącznie do sankcji podatkowych oraz karnoskarbowych.

W prawie międzynarodowym problem zbiegu sankcji uregulowany został w art. 4 ust. 1 Protokołu Nr 7 (Zakaz ponownego sądzenia lub karania), zgodnie z którym nikt nie może być ponownie sądzony lub ukarany w postępowaniu przed sądem tego samego państwa za przestępstwo, za które został uprzednio skazany prawomocnym wyrokiem lub uniewinniony zgodnie z ustawą i zasadami postępowania karnego tego państwa.

31 Zob. szerzej P. Majka, Sankcje w prawie podatkowym..., s. 228-231. 
Z powyższej zasady ne bis in idem wynika, że jednostka nie może być ścigana, uznana za winną ani karana przez sądy tego samego państwa za przestępstwo, w związku z którym została wcześniej uniewinniona albo skazana na podstawie wydanego zgodnie z prawem prawomocnego wyro$\mathrm{ku}^{32}$. W orzecznictwie ETPC dla oceny kolejnego przeprowadzanego postępowania karnego jako „powtórzonego” (tzn. tożsamego z tym już przeprowadzonym) wskazuje się, że uwzględnić należy m.in. to: czy postępowania toczyły się według odrębnej procedury, czy wydane w ich toku orzeczenia stały się prawomocne niezależnie od siebie ${ }^{33}$, czy sankcja wymierzona jako pierwsza była brana pod uwagę przy określeniu dolegliwości drugiej sankcji ${ }^{34}$, czy fakty ustalone w jednym z postępowań zostały przywołane w drugim oraz to, czy nakładane kary tworzą łącznie ogólny system sankcji ${ }^{35}$. Tym samym w wypadku prowadzonych postępowań karnego i związanego ze stosowaniem sankcji podatkowej ocenie podlegać będzie to, czy prowadzone postępowania cechuje bliski związek co do oceny tego samego zachowania, tych samych osób w tym samym czasie ${ }^{36}$.

Jednocześnie ocena tego, czy w wypadku sankcji podatkowych występuje zjawisko zbiegu z sankcjami karnymi, jest uzależniona od uznania danej instytucji za sankcję (karę) podlegającą rygorom Konwencji. Z kolei uznanie określonej instytucji za sankcję oparte jest na przyjętej w doktrynie oraz orzecznictwie konwencji ${ }^{37}$, co powoduje, że na tym tle powsta-

32 M. Nowicki, Komentarz do Protokołu Nr 7 do Konwencji o ochronie praw człowieka i podstawowych wolności [w:] Wokół Konwencji Europejskiej. Komentarz do Europejskiej Konwencji Praw Człowieka, wyd. VII, LEX/el. 2021.

33 Wyrok ETPC z 27 listopada 2014 r. w sprawie Lucky Dev przeciwko Szwecji, nr 7356/10, www.hudoc.echr.coe.int.

34 Wyrok ETPC z 20 maja 2014 r. w sprawie Nykänen przeciwko Finlandii, nr 11828/11, LEX nr 1460651.

35 Wyrok ETPC z 15 listopada 2016 r. w sprawie A. i B. przeciwko Norwegii, nr 24130/11 i 29758/11, LEX nr 2147740.

36 Wyrok ETPC z 18 maja 2017 r. w sprawie Johannesson i inni przeciwko Islandii, nr 22007/11, LEX nr 2286528. Zob. także odnośnie do sankcji polegającej na grzywnie wymierzonej przez Komisję do spraw Przedsiębiorstw Państwowych i Giełd w związku z „manipulacjami rynkowymi” niestanowiącymi przestępstwa w prawie włoskim - wyrok ETPC z 4 marca 2014 r. w sprawie Grande Stevens i inni przeciwko Włochom, nr 18640/10, LEX nr 1663433.

37 W wyrokach ETPC nie formułowano definicji sankcji podatkowych, wskazywano natomiast, że w sprawach wymierzona została „sankcja”, ,sankcja podatkowa”, „sank- 
wać będą wątpliwości odnośnie do kryteriów, które decydują o kwalifikacji danej instytucji jako sankcji. W wyroku ETPC z 7 czerwca 2008 r. w sprawie Zolothukin przeciwko Rosji ${ }^{38}$ uznano, że terminy „w postępowaniu przed sądem” oraz ,zasady postępowania karnego” przewidziane w art. 4 Protokołu nr 7 muszą być interpretowane w świetle ogólnych zasad dotyczących związanych z nimi słów „oskarżenie w sprawie karnej” i „kary” m.in. w art. 6 Konwencji ${ }^{39}$. Zgodnie z art. 6 ust. 1 zd. 1 Konwencji każdy ma prawo do sprawiedliwego i publicznego rozpatrzenia jego sprawy w rozsądnym terminie przez niezawisły i bezstronny sąd ustanowiony ustawą przy rozstrzyganiu o jego prawach i obowiązkach o charakterze cywilnym albo o zasadności każdego oskarżenia w wytoczonej przeciwko niemu sprawie karnej. Powstaje w tym miejscu wymagająca rozstrzygnięcia wątpliwość co do tego, czy regulacje art. 6 ust. 1 Konwencji oraz art. 4 Protokołu nr 7 znajdują zastosowanie do spraw podatkowych ${ }^{40}$.

Problem zakresu, w jakim postanowienia Konwencji dotyczą spraw związanych z zobowiązaniami podatkowymi, był wielokrotnie rozstrzygany w orzeczeniach ETPC oraz Europejskiej Komisji Praw Człowieka, które na gruncie poszczególnych przepisów Konwencji ustalały kryteria mające rozgraniczyć sprawy podatkowe oraz karne i cywilne.

Trybunał, odnosząc się do stosowania art. 6 Konwencji, ustalił ogólną regułę, zgodnie z którą gwarancja prawa do słusznego procesu wynikająca z treści tego przepisu nie znajduje zastosowania w sprawach podatkowych $^{41}$. Od zasady tej przewidziano jednak wyjątki. Przede wszystkim

cja administracyjna”, „kara podatkowa”, „dopłata podatkowa”, „dodatkowy podatek”, „dodatkowa opłata podatkowa”, „dodatkowe obciążanie podatkowe” lub „dodatkowy wymiar opodatkowania”, nie precyzując tych pojęć oraz nie dokonując szerszych kwalifikacji.

$38 \mathrm{Nr}$ 14939/03, LEX nr 289975.

39 Zob. M. Szwarc, Łqczne zastosowanie sankcji administracyjnych i karnych w świetle zasady ne bis in idem (uwagi na tle orzecznictwa ETPC), „Państwo i Prawo” 2017, nr 12, s. 43-56.

40 Zob. szerzej A. Brzezińska-Rawa, A. Franczak, Poglądy nauki prawa podatkowego na stosowanie art. 6 ust. 1 EKPC $w$ sprawach podatkowych [w:] A. Franczak (red.), Ochrona praw podatnika. Diagnoza sytuacji, Warszawa 2021, s. 55-67.

41 Zob. szerzej M. Balcerzak, A. Zalasiński, Sqdowo-administracyjna kontrola decyzji podatkowych a prawo do rzetelnego procesu (art. 6 Europejskiej Konwencji Praw Człowieka), „Kwartalnik Prawa Podatkowego” 2002, nr 1, s. 41-43; C. Campbell, 
ETPC dopuszcza traktowanie jako spraw z zakresu „praw i obowiązków o charakterze cywilnym” spraw dotyczących zwrotu nadpłaty ${ }^{42}$ oraz środka w postaci zajęcia udziałów mającego na celu zabezpieczenie uiszczenia należności podatkowych ${ }^{43}$. Z kolei zakres pojęcia „sprawy karnej”, o którym mowa $\mathrm{w}$ art. 6 Konwencji, jest szerszy niż sprawy rozstrzyganej w oparciu o regulacje procedury karnej związanej z popełnionym przestępstwem lub wykroczeniem. W zakresie pojęcia „sprawy karnej” mogą mieścić się bowiem postępowania związane ze stosowaniem sankcji podatkowych. Przepisy Konwencji znajdują zatem zastosowanie do sytuacji, w których pomimo że zgodnie z krajowymi przepisami sprawa ma charakter podatkowej występuje w niej zagadnienie „oskarżenia karnego”. Trybunał uznaje przy tym, że sankcja jest związana z oskarżeniem karnym w rozumieniu art. 6 Konwencji niezależnie od rodzaju procedury, w jakiej jest stosowana, jeżeli natura czynu, którego popełnienie skutkuje nałożeniem sankcji (decyduje głównie to, czy właściwe są przepisy prawa publicznego oraz czyn jest przestępstwem) lub dotkliwość wymierzanej sankcji (rodzaj sankcji oraz jej surowość) powodują, iż sankcji tej można przypisać charakter kary ${ }^{44}$.

Wskazania odnośnie do kwalifikacji sankcji podatkowych jako karnych wynikają z orzecznictwa ETPC. W wyroku ETPC z 23 listopada 1976 r. $w$ sprawie Engel $i$ inni przeciwko Holandii ${ }^{45}$ jako $w$ jednym z pierwszych orzeczeń uznano, że o tym, czy w sprawie prowadzone jest postępowanie karne, decydować powinno kryterium zaliczenia w państwie danego kraju do postępowania karnego, przy czym brak takiego

Application of the Charter to Civil Penalties in The Income Tax Act, „Canadian Tax Journal” 2002, nr 50, s. 4-9; A. Leszczyńska, Europejska Konwencja..., s. 29-33 i powołane tam orzecznictwo, w tym wyrok ETPC z 12 lipca 2001 r. w sprawie Ferrazzini przeciwko Włochom, $\mathrm{nr}$ 44759/98.

42 Wyrok ETPC z 9 marca 2006 r. w sprawie Eko-Elda AVEE przeciwko Grecji, nr 10162/02, LEX nr 253657.

43 Wyrok ETPC z 1 lutego 2011 r. w sprawie Metalco Bt. przeciwko Węgrom, nr 34976/05, LEX nr 69385.

44 Zob. A. Leszczyńska, Europejska Konwencja..., s. 34; D. Szumiło-Kulczycka, Prawo administracyjno-karne, Kraków 2004, s. 78-80.

45 Nr 5100/71, LEX nr 80797; zob. K. Szczechowicz, Tożsamość postępowania karnego i karnoskarbowego a powaga rzeczy osq̨dzonej, „Studia Prawnoustrojowe” 2021, nr 52, s. 481. 
zaliczenia nie decyduje o traktowaniu jako niepodlegające regulacjom Konwencji. Postępowanie takie dla potrzeb Konwencji jest postępowaniem karnym, o ile natura czynu skutkującego nałożeniem sankcji ma charakter przestępny, a czyn ten regulowany jest prawem publicznym oraz grożąca sankcja jest dotkliwa.

W wyroku ETPC z 24 lutego 1994 r. w sprawie Bendenoun przeciwko Francji ${ }^{46}$ uznano, że w stosunku do wymierzania „opłat podatkowych” w wysokości 50\% należnego podatku (będących zgodnie z prawem francuskim wyłącznie karami administracyjnymi, z uwagi na to, że obejmują one zakresem podmiotowym wszystkich obywateli, mają na celu zarówno odstraszenie od ponownego naruszenia prawa, jak i ukaranie oraz w sytuacji braku zapłaty powodują ukaranie karą pozbawienia wolności wymierzoną przez sąd karny) należy stosować art. 6 Konwencji. W orzeczeniu tym powołano cztery następujące istotne elementy, które należy ustalić: czy przepis prawa podatkowego przewidujący sankcję ma charakter ogólny i daje się zastosować wobec każdego podatnika, a nie wyłącznie ograniczonej grupy; czy wymierzona sankcja podatkowa z założenia jest traktowane jako kara, a nie jako odszkodowanie; czy sankcje wymierzane są według ogólnej normy, która określa dokładnie zachowanie nią zagrożone i ma na celu nie tyko ukaranie, ale również prewencję generalną; czy sankcje są dolegliwe. Jednocześnie uznano, że instytucja musi spełniać wszystkie powyższe warunki, by uznać ją jako sankcję objętą zakresem art. 6 Konwencji ${ }^{47}$. Odmienne stanowisko co do obowiązku kumulowania przesłanek przyjęto z kolei w orzeczeniu ETPC z 23 lipca 2002 r. w sprawie Västberga Taxi $A B$ and Vulic przeciwko Szwecji ${ }^{48}$ dotyczącego nałożenia zgodnie z prawem podatkowym Szwecji na podatnika dodatkowych „opłaty podatkowych” w wysokości $20 \%$ oraz $40 \%$ kwoty zaniżonego zobowiązania. Postępowanie związane z wymiarem tych opłat zostało uznane przez ETPC za postępowanie w sprawie karnej. Trybunał wskazał przy tym, że zasadniczo spory podatkowe nie wchodzą w zakres stosowa-

46 Nr 12547/86 [w:] T. Jasudowicz, Orzeczenia strasburskie. Zbiór orzeczeń za lata 1990-1997, Torun 1997, s. 160-162 i 231-232.

47 B. Szczurek, Koncepcja ochrony praw..., s. 104.

48 Nr 36985/97, LEX nr 75485. 
nia „praw i obowiązków o charakterze cywilnym” z art. 6 Konwencji pomimo skutków finansowych, które bezsprzecznie wywołują dla podatnika. Jednocześnie z uwagi na nałożony obowiązek uiszczenia dodatkowych opłat podatkowych pojawia się wątpliwość, czy postępowanie w sprawie było związane z rozstrzygnięciem „oskarżenia w sprawie karnej”, które w rozumieniu art. 6 Konwencji ma charakter autonomiczny. Trybunał uznał, że rozstrzygając to, czy dany czyn kwalifikuje się jako „karny”, należy stosować trzy kryteria: kwalifikację prawną czynu w prawie krajowym, charakter czynu oraz charakter i stopień dolegliwości ewentualnej kary ${ }^{49}$. Jednocześnie należy dokonywać oceny, czy sankcje podatkowe spełniają którekolwiek ze wskazanych wyżej kryteriów. Kryteria te zostały zatem uznane za alternatywne, a nie kumulatywne ${ }^{50}$. Dla zastosowania art. 6 Konwencji w odniesieniu do słów „oskarżenie w sprawie karnej” wystarcza zatem, by przedmiotowy czyn był ze swej istoty „karny” z punktu widzenia Konwencji lub poddawał zainteresowaną osobę sankcji, która ze swej istoty i stopnia dolegliwości należy co do zasady do sfery „karnej”. Nie wyklucza to oczywiście przyjęcia podejścia kumulatywnego, kiedy to odrębna analiza każdego ze wskazanych kryteriów nie daje możliwości wywiedzenia jasnego wniosku co do istnienia „oskarżenia w sprawie karnej”. Rozstrzygając sprawę kwalifikacji dodatkowych zobowiązań podatkowych w prawie szwedzkim, ETPC stwierdził, że ogólny charakter przepisów prawnych ich dotyczących i celu kar, które mają charakter zarówno odstraszający, jak i karzący ${ }^{51}$, a także dolegliwość ewentualnej i rzeczywistej sankcji wystarczają, by wykazać dla celów art. 6 Konwencji, że postępowania wobec skarżących toczyły się w sprawie karnej.

Także w aktualnym orzecznictwie ETPC przyjmuje się tezę, że rozstrzygając o istnieniu „oskarżenia w sprawie karnej”, należy wziąć pod uwagę prawną klasyfikację przedmiotowego środka w prawie krajowym,

49 Por. wyrok ETPC z 29 sierpnia 1997 r. w sprawie A.P., M.P. I T.P. przeciwko Szwajcarii, nr 19958/92, LEX nr 79644.

50 Zob. również decyzję ETPC z 15 czerwca 1999 r. w sprawie W.S. przeciwko Polsce, nr 37607/97, LEX nr 41102.

51 Podobnie ETPC w wyroku z 16 czerwca 2009 r. w sprawie Ruotsalainen przeciwko Finlandii, nr 13079/03, LEX nr 504350. 
samą istotę środka oraz charakter i stopień dolegliwości „kary”, rozumiejąc je alternatywnie ${ }^{52}$.

W świetle powyższych orzeczeń powstaje wątpliwość, czy odniesieniu do sankcji podatkowych przewidzianych w prawie polskim konieczność stosowania art. 6 Konwencji i tym samym przewidzianego w art. 4 ust. 1 Protokołu nr 7 zakazu podwójnego karania, dotyczy wszystkich rodzajów sankcji. Jakkolwiek wszystkie sankcje podatkowe związane są bowiem z dolegliwością, to nie wszystkim można jednak przypisać naturę „karną”, do której odwołuje się w orzeczeniach ETPC, m.in. z uwagi na brak elementu represji rozumianej jako odwet za naruszenie prawa ${ }^{53}$. Dodatkowo część sankcji w polskim prawie podatkowym cechuje stosunkowo niewielki stopień dolegliwości.

Należy stwierdzić, że orzecznictwo ETPC pozwala uznać „karny” charakter w rozumieniu regulacji Konwencji tych sankcji podatkowych w prawie polskim, które polegają na wymierzeniu dodatkowego zobowiązania podatkowego, w sytuacji gdy odpowiednio wysoki jest stopień ich dolegliwości. W kolei w odniesieniu do spraw związanych ze stosowaniem sankcji polegających na utracie uprawnień z uwagi na to, że ich charakter powoduje wymierzanie ich wyłącznie przy obliczaniu prawidłowej wysokości podatku, zgodnie $\mathrm{z}$ kryteriami ustalonymi w orzeczeniach ETPC nie będą kwalifikowane jako „sprawy karne” w rozumieniu art. 6 Konwencji.

Natomiast w odniesieniu do sankcji polegających na podwyższeniu stawek lub podstaw opodatkowania kwestia uznania ich za „karne” w rozumieniu Konwencji jest bardziej skomplikowana ${ }^{54}$, ponieważ wskazane wyżej orzeczenia ETPC odnosiły się do sytuacji, w których nastę-

52 Tak przykładowo ETPC w powołanym wyżej wyroku z 4 marca 2014 r. w sprawie Grande Stevens i inni przeciwko Włochom, nr 18640/10.

53 Zob. szerzej na temat rozumienia elementu represji oraz odpłaty w sankcjach administracyjnych oraz karnych - M. Mozgawa, M. Kulik, Wybrane zagadnienia z zakresu wzajemnego stosunku odpowiedzialności karnej i administracyjnej, „Ius Novum” 2016, nr 3, s. 41.

54 Zob. np. wyrok WSA w Olsztynie z 29 września 2011 r., I SA/Ol 488/11 (CBOSA), w którym uznano, że wymiar ryczałtu od przychodów niezaewidencjonowanych i jednocześnie kary za przestępstwo lub wykroczenie skarbowe nie narusza zasady podwójnego karania, także w rozumieniu Konwencji. 
powało wyłącznie obciążenie podatnika dodatkowym zobowiązaniem podatkowym (dopłatą). Wydaje się jednocześnie, że przyjęte w powołanych orzeczeniach ETPC kryterium dotkliwość wymierzanej sankcji, które umożliwia ocenę, czy sprawa ma charakter karnej, należy stosować również do sankcji polegających na podwyższeniu podatku ${ }^{55}$ na skutek zwiększenia stawki lub podstawy opodatkowania. Założenie to powoduje, że w sytuacji podwyższenia stawki lub podstawy opodatkowania w stopniu, który spowodowałby uznanie sankcji za odpowiednio dotkliwą oraz ustaleniu innych wynikających z powołanych wyżej orzeczeń „karnych” cech, sankcję można by zakwalifikować jako karną. Problemem, który należy rozstrzygać indywidualnie w odniesieniu do poszczególnych sankcji, jest natomiast wysokość „zwyżki”, której przekroczenie powodowałoby uznanie sprawy związanej z wymierzeniem tej sankcji jako „karnej”. Wydaje się jednocześnie, że aktualnie obowiązujące przepisy nie przewidują w polskim prawie podatkowym sankcji, których charakter oraz stopień dolegliwości pozwoliłyby je uznać za spełniające kryteria sankcji karnych, które przyjmuje ETPC ${ }^{56}$.

\section{Podsumowanie}

Przedstawione problemy związane z kumulacją odpowiedzialności z tytułu sankcji podatkowych oraz odpowiedzialności karnej wymagają każdorazowo ich uwzględnienia zarówno przez racjonalnego ustawodawcę, jak i przez organy stosujące prawo. Podstawą proponowanych rozwiązań

55 Por. K. Wojtyczek, Ochrona praw podatnika w orzecznictwie Europejskiego Trybunału Praw Człowieka [w:] A. Franczak (red.), Ochrona praw podatnika. Diagnoza sytuacji, Warszawa 2021, s. 420.

56 Obecnie sankcjami podatkowymi związanymi z podwyższeniem stawki podatkowej są: maksymalne stawki ryczałtu od przychodów ewidencjonowanych; podwyższona stawka w wysokości pięciokrotnej stawki ryczałtu od przychodów ewidencjonowanych (nie większa niż 75\%); opodatkowanie przychodów z nieujawnionych źródeł przychodów lub nieznajdujących pokrycia w ujawnionych źródłach przychodów podatkiem z zastosowaniem stawki 75\%; liczne stawki sankcyjne w podatku akcyzowym; 20\% stawki sankcyjne w podatku od spadków i darowizn oraz podatku od czynności cywilnoprawnych. Nie występują obecnie sankcje związane z podwyższeniem podstawy opodatkowania. 
w zakresie stanowienia i stosowania prawa powinno być przy tym wynikające z prawa zarówno krajowego, jak i międzynarodowego założenie eliminacji możliwości stosowania jednocześnie sankcji podatkowych oraz karnych z uwagi na uniwersalną zasadę niedopuszczalności wielokrotnego karania tej samej osoby za ten sam czyn. Jednocześnie granice w tym zakresie wynikają z art. 4 ust. 1 Protokołu nr 7, którego treść precyzuje przedstawione wyżej orzecznictwo ETPC. Stosowanie zasady ne bis in idem w celu uniknięcia zbiegu sankcji podatkowych z karnoskarbowymi wymaga, by w pierwszej kolejności dokonać oceny sankcji podatkowej jako karnej w oparciu o kryteria przyjmowane w orzecznictwie Trybunału. Pojawiają się wówczas liczne problemy związane z oceną sankcji podatkowych jako podlegających Konwencji, ponieważ współcześnie nie funkcjonują one jako wykształcona i stabilna instytucja prawna. Stosunkowo krótkie tradycje stosowania sankcji podatkowych w ich obecnej postaci, duża różnorodność, brak jednoznacznej i konsekwentnej polityki odnośnie do ich wprowadzania do systemu prawnego, a także niejednoznaczny charakter prawny powodują, że ustalanie tego, czy może dojść do zabronionego zbiegu sankcji, wywoływać będzie wątpliwości. W rozwiązaniu powyższego problemu pomocne będzie, jeżeli na etapie tworzenia sankcji wykorzystane zostaną jednoznaczne oraz czytelne kryteria delimitujące zakres sankcji.

\section{Bibliografia:}

Balcerzak M., Zalasiński A., Sqqdowo-administracyjna kontrola decyzji podatkowych a prawo do rzetelnego procesu (art. 6 Europejskiej Konwencji Praw Człowieka), „Kwartalnik Prawa Podatkowego” 2002, nr 1, s. 39-51.

Brzezińska-Rawa A., Franczak A., Poglqdy nauki prawa podatkowego na stosowanie art. 6 ust. 1 EKPC w sprawach podatkowych [w:] A. Franczak (red.), Ochrona praw podatnika. Diagnoza sytuacji, Wolters Kluwer, Warszawa 2021.

Brzeziński B., Prawo podatkowe. Zagadnienia teorii i praktyki, TNOiK, Toruń 2017.

Buchała K., Zoll A., Polskie prawo karne, Wydawnictwo Prawnicze PWN, Warszawa 1997.

Campbell C., Application of the Charter to Civil Penalties in The Income Tax Act, „Canadian Tax Journal” 2002, nr 50, s. 1-27. 
Cieślak M., O węzłowych pojęciach zwiqzzanych z sensem kary, „Państwo i Prawo" 1969, nr 2, s. 195-213.

Duda M., Pojęcie i charakter sankcji podatkowych, „Prawo-AdministracjaKościół” 2002, nr 2-3, s. 26-37.

Dzwonkowski H., Konstytucyjność sankcji podatkowych, „Monitor Podatkowy” 1999, nr 3, s. 22-28.

Gomułowicz A., Małecki J., Podatki i prawo podatkowe, Wydawnictwo Prawnicze LexisNexis, Warszawa 2006.

Gontarczyk M., Sankcje finansowe i karne skarbowe jako instrument ochrony publicznej gospodarki finansowej, niepublikowana praca doktorska, Lublin 2006.

Jasudowicz T., Orzeczenia strasburskie. Zbiór orzeczeń za lata 1990-1997, TNOiK, Toruń 1997.

Leszczyńska A., Europejska Konwencja o Ochronie Praw Człowieka oraz Podstawowych Wolności jako instrument ochrony praw podatnika, „Kwartalnik Prawa Podatkowego" 2004, nr 1-2, s. 9-49.

Majewski J. [w:] A. Zoll (red.), Kodeks karny. Część ogólna. Komentarz, Tom I, Zakamycze, Kraków 2004.

Majka P., Sankcje w prawie podatkowym, C.H. Beck, Warszawa 2011.

Małecki J., Z problematyki sankcji w prawie podatkowym ze szczególnym uwzględnieniem podatku VAT [w:] B. Brzeziński, J. Głuchowski, C. Kosikowski, R. Mastalski (red.) Księga pamiq̨tkowa ku czci prof. A. Kosteckiego. Studia z dziedziny prawa podatkowego, TNOiK, Toruń 1998.

Marek A., Prawo karne, C.H. Beck, Warszawa 2005.

Mozgawa M., Kulik M., Wybrane zagadnienia z zakresu wzajemnego stosunku odpowiedzialności karnej i administracyjnej, „Ius Novum” 2016, nr 3, s. 31-63.

Mudrecki A., Ochrona praw podatników w świetle orzecznictwa Europejskiego Trybunału Praw Człowieka w Strasburgu, „Krytyka Prawa” 2020, nr 1, s. 132-148.

Nowicki M., Komentarz do Protokołu Nr 7 do Konwencji o ochronie praw człowieka i podstawowych wolności [w:] Wokół Konwencji Europejskiej. Komentarz do Europejskiej Konwencji Praw Człowieka, wyd. VII, LEX/el. 2021.

Szczechowicz K., Tożsamość postępowania karnego i karnoskarbowego a powaga rzeczy osq̨dzonej, „Studia Prawnoustrojowe” 2021, nr 52, s. 477-488.

Szczurek B., Koncepcja ochrony praw podatnika. Geneza, rozwój, perspektywy, C.H. Beck, Warszawa 2008.

Szumiło-Kulczycka D., Prawo administracyjno-karne, Zakamycze, Kraków 2004. 
Szwarc M., Łqczne zastosowanie sankcji administracyjnych i karnych w świetle zasady ne bis in idem (uwagi na tle orzecznictwa ETPC), „Państwo i Prawo” 2017, nr 12, s. 43-56.

Wilk L., Zagadnienia materialnego prawa karnego skarbowego, TNOiK, Toruń 2004.

Wojtyczek K., Ochrona praw podatnika w orzecznictwie Europejskiego Trybunału Praw Człowieka [w:] A. Franczak (red.), Ochrona praw podatnika. Diagnoza sytuacji, Wolters Kluwer, Warszawa 2021.

Wójtowicz W., Przestępstwa i wykroczenia podatkowe, „Monitor Podatkowy” 1995, nr 1, s. 4-8.

Zoll A., Założenia polityki karnej w projekcie kodeksu karnego, „Państwo i Prawo" 1994, nr 5, s 12-19. 